\title{
International law as a help or hinderance to world peace
}

Article

Accepted Version

Gilder, A. ORCID: https://orcid.org/0000-0002-8861-1433

(2020) International law as a help or hinderance to world peace. Journal of International Humanitarian Legal Studies, 11 (2). pp. 447-459. ISSN 1878-1527 doi:

https://doi.org/10.1163/18781527-bja10021 Available at https://centaur.reading.ac.uk/101390/

It is advisable to refer to the publisher's version if you intend to cite from the work. See Guidance on citing.

To link to this article DOI: http://dx.doi.org/10.1163/18781527-bja10021

Publisher: Brill

All outputs in CentAUR are protected by Intellectual Property Rights law, including copyright law. Copyright and IPR is retained by the creators or other copyright holders. Terms and conditions for use of this material are defined in the End User Agreement.

\section{www.reading.ac.uk/centaur}

\section{CentAUR}

Central Archive at the University of Reading 
Reading's research outputs online 


\title{
International Law as a Help or Hinderance to World Peace
}

\section{Review Essay}

\author{
Alexander Gilder \\ Lecturer in Law, Royal Holloway, University of London \\ Alexander.Gilder@rhul.ac.uk
}

\begin{abstract}
Alex J Bellamy
World Peace (And How We Can Achieve It) (Oxford University Press 2019), 9780198833529, 288pp, GBP 20.00
\end{abstract}

\begin{abstract}
World Peace (And How We Can Achieve It) looks towards a future where there is increasingly optimistic engagement with the concept of peace. Bellamy assesses why the world is the way it is before making suggestions for how the world can achieve peace. Bellamy suggests world peace is achievable and in the final chapter constructs his articles for world peace. This review essay engages with several themes in the book looking at how the history of international law is framed by the author before assessing Bellamy's arguments in relation to the state and international organisations. Lastly, the essay casts a legal eye over the author's articles for world peace. The articles will be of particular interest to readers in international law as they are embedded in the existing systems and structures of the prevailing international system. However, the articles contain the important inclusion of individuals and the role they play in achieving world peace. World Peace allows international lawyers to think more deeply about peace and the points made in this essay raise some issues that may be further debated as scholars map the paths to peace.
\end{abstract}

\section{Keywords}

International peace and security - international humanitarian law - history of international law - TWAIL - international organizations

\section{Introduction}

While not a book that directly addresses international law throughout, this is a text that has the potential to (re)shape the thinking of international legal scholars when it comes to peace. Alex Bellamy systematically breaks down many preconceptions about peace that are woven into our traditional understandings of international law. Key to Bellamy's discussions of world peace 
are threads commonly found in international law scholarship, such as how it is a system constructed to bring states together to peacefully settle disputes and how international organisations are collectives that share values. It is rare to read a book that makes such profound claims in the opening pages that lay out a vision of the achievability of peace by overturning traditional understandings with ease. The first section of the book (Chapters 1-4) address the background of world peace and assesses theories for why the world is the way it is. The second section (Chapters 5-8) forms Bellamy's assessment of how we can move towards world peace. A rich amount of content is covered with Bellamy giving a history of peace (Chapter 2), discussing whether humans are hard wired for war (Chapter 3), outlining how war is a contagion (Chapter 4), the continuing importance of the state (Chapter 5), the different costs of war (Chapter 6), the seemingly endless passion for war (Chapter 7), and lastly Bellamy's articles for peace (Chapter 8). This review engages with the book by highlighting some areas where critiques could arise in international law with attention given to the systems and regimes which may help or hinder the achievement of peace. The review discusses issues, such as whether international humanitarian law (IHL) represents an effort to achieve peace, the role of the state, the universality of international law, and the legitimacy of international law in an interlinked and ever-connected global community.

Before exploring the book in greater depth, it is important to try to summarise Bellamy's vision of peace in Chapter 1 . The book challenges the reader to view the pursuit of world peace as a serious question and not to become disillusioned by world peace as 'naïve and utopian' or an 'intellectual fantasy' ( $p$ p 3,1). Bellamy recounts the decline of inter-state conflict and the rise of civil wars that today bring increased violence against civilians. Attention is also drawn to how the discussion of foreign affairs in the West is often dominated by the decline of the liberal and rules-based international order ( $p$ 3). Bellamy suggests the West has this preoccupation due to how war is seen to be universal and how peace is believed to be the anomaly while war remains 'part of the human condition' ( $p$ 4). Arguing world peace is possible Bellamy suggests; (1) peace is more common than we think; (2) we are not living through a decline of the liberal rules-based order; and (3) both war and peace are human creations (pp 5-9). To understand what is needed to achieve peace, Bellamy offers a definition of the term as 'the absence and prevention of war (international and civil) and the management of conflict through peaceful means, implying some form of legitimate civil order' ( $p$ 17). In discussing what peace involves Bellamy offers a critique of Galtung's conception of 'positive peace' as the values of leftist European ideologies 'masquerading as a great universal vision of peace' and similarly challenges the notion of justice within peace (pp 15-16). ${ }^{1}$ Importantly, Bellamy sets the scene by asking the reader to view world peace not as a single grand project but instead as the result of multiple minor utopias that are possible (p 19).

\section{The history of international law}

The first area for critique is the history of peace and the coverage given to public international law. For international lawyers, whose history tend to begin in the 15-1600s with Hugo Grotius and the various other 'fathers of international law', it is useful that Bellamy draws on Greek progress on creating 'peace leagues' ( $p$ 25), early Indian doctrines on peace in the eight century

\footnotetext{
${ }^{1}$ See, eg, Johan Galtung, 'Peace, Positive and Negative' in Daniel J Christie (ed), The Encyclopedia of Peace Psychology (Wiley 2011).
} 
BCE (pp 25-26), Confucian and Daoist understandings of peace (p 26), and the Roman Empire's Pax Romana (pp 26-30). Later philosophies and theories of peace are discussed such as Erasmus' thoughts on how to achieve peace (p 31) and Kant's Perpetual Peace (pp 34-37). International law is mentioned once we reach the work of Jeremy Bentham ( $p$ 38). This means there is an unusual omission of Grotius and his theories on just war that fundamentally defended the morality of war and embedded into international law the right of states to amass territory and property through war. Instead Bellamy focuses on how nineteenth century liberals sought to promote free trade and international law as an effort to 'bind peoples together into a common humanity' ( pp 38-39). The issue though is that the foundations of international law are much less inclusive, focused on the self-interest of states, and ultimately resulted in the subjugation of much of the world. A significant intellectual history that includes an in-depth account of Grotius's thinking, alongside other key developments in international law, has been recently provided by Oona Hathaway and Scott Shapiro in The Internationalists. ${ }^{2}$ Hathaway and Shapiro note that Grotius believed war was good and can be used to right a wrong such as collecting debts. ${ }^{3}$ His work also argues that navigation of the high seas is a natural right that we all possess as human beings. The problem though is that Grotius's theories on international law were not applied to all human beings and natural rights were not applied when European powers conquered new territory. Scholars such as Alberico Gentili used international law to justify punitive war where deeds committed by native peoples were deemed to be particularly brutal and horrible by civilised European standards. ${ }^{4}$

Jean d'Aspremont has lamented how international lawyers were the 'complacent recipients' of linear histories that were reproduced in scholarship until the more recent turn to critical histories that have rejected the liberal concept of history. ${ }^{5}$ D'Aspremont calls for research to go further and undertake radical historical critique to break from the traditional restrictions that have repressed the imagination of researchers. ${ }^{6}$ Academics must be critical of international law's origins to avoid displaying international law as founded upon a 'common humanity' when that is far from the case. Bellamy's history is not a radical critique which could hinder its usefulness for considering how we can best move toward peace today. That is to say, in the words of d'Aspremont, we must constantly re-write histories and counter-histories to rejuvenate disciplinary imagination. ${ }^{7}$ The same applies to thinking on peace. We must more closely assess the underlying assumptions found in histories of law and peace that are limiting our thinking on how best to strive for world peace.

There is a similar lack of critique with regards to the 1899 and 1907 Hague Conferences and the resulting conventions ( $\mathrm{pp} 40-42$ ). Bellamy suggests the Hague Conventions enshrine ideas central to peace into international law for the first time noting the Conferences agreed the Convention for the Pacific Settlement of International Disputes and Convention respecting the Laws and Customs of War on Land. However, some critical scholars could argue the latter, which codified and expanded aspects of IHL, in fact perpetuates conflict as a legal, and by

\footnotetext{
${ }^{2}$ Oona A Hathaway and Scott J Shapiro, The Internationalists: And Their Plan to Outlaw War (Penguin 2018). See Chapter 1, 'Hugo the Great' 3.

${ }^{3}$ Ibid. 9.

${ }^{4}$ Ibid. 48-9.

${ }^{5}$ Jean d'Aspremont, 'Critical histories of international law and the repression of disciplinary imagination' (2019) 7 London Review of International Law 89, 91.

${ }^{6}$ Ibid. 102.

${ }^{7}$ Ibid. 112 .
} 
extension, morally justified endeavour for a state to pursue ${ }^{8}$ Chris af Jochnick and Roger Normand forcefully argue IHL 'legitimate[s] ever more destructive methods of combat' with the Hague Conventions in particular upholding, not restricting, military necessity. ${ }^{9}$ Alison Duxbury has argued the classification of a conflict and whether IHL applies to a situation 'creates silences about other types of conflict and violence that are not defined as armed conflicts' removing certain types of suffering from the discussion and undermining IHL's claim to humanity. ${ }^{10}$ Bellamy suffers from Duxbury's perceived trap of the claim that IHL is focused on humanity. By assuming IHL's inherent humanity, scholars are limited in their ability to criticise the regime and its boundaries. ${ }^{11}$

Helen Durham has conversely made the point that IHL's pragmatic usefulness for engaging non-state actors, influencing those in positions of power, and sparking the advent of numerous tribunals and courts to enforcement IHL, has overcome suggestions that the law legitimises violence. ${ }^{12}$ However, we must be careful when we discuss larger projects such as world peace. IHL may have pragmatic usefulness when conflict exists in the current status quo but what about for creating a world where peace reigns and conflict is confined to the history books? When thinking about war IHL has a purpose, but when thinking about peace it is difficult to move past Jochnick and Normand's legitimation of violence. In this sense the advancement of IHL as an idea central to peace could also contradict some of Bellamy's initial observations in Chapter 1. For instance, Bellamy does recognise IHL cannot always prevent the escalation of war ( $p$ 92), but could IHL make war more contagious? As IHL continues to be pragmatically useful by shielding civilian populations from the worst effects of war, the regulations consequently continue to be appetising to states around the world, preventing the more iconoclastic thinking necessary for world peace.

\section{The state and international organisations}

In Chapter 4 Bellamy asks why war persists? Bellamy is undeterred in his belief war persists because of 'the way we organize ourselves, because war has proven itself productive at times, and because war is contagious' ( $p$ 73). Bellamy's first reason, organisation, is rooted in how we are divided into sub-groups. We inherently prioritise the needs of our kin over others be that within familial, religious, ethnic or national groups. Bellamy suggests though that states have found peaceful means of co-existence both within their boundaries and on the international plane with the proliferation of peaceful dispute settlement, international human rights law and a wealth of international organisations ( $\mathrm{pp}$ 77-78). Ultimately Bellamy argues the state is 'indispensable to the cause of word peace' ( $p$ 97). Bellamy relies on the evidence that states today have 'unparalleled destructive capabilities' but they nevertheless provide more peaceful lives than humans would have in their absence ( $p$ 100). Bellamy outlines five

\footnotetext{
${ }^{8}$ See, eg, Chris af Jochnick and Roger Normand, 'The Legitimation of Violence: A Critical History of the Laws of War' (1994) 35 Harvard International Law Journal 49.

${ }^{9}$ Ibid. 51, 68.

${ }^{10}$ Alison Duxbury, 'Drawing Lines in the Sand - Characterising Conflicts for the

Purposes of Teaching International Humanitarian Law' (2007) 8 Melbourne Journal of International Law 259, 268.

${ }^{11}$ Ibid. 270.

${ }^{12}$ Helen Durham, 'International Humanitarian Law and the Gods of War: The Story of

Athena versus Ares' (2007) 8 Melbourne Journal of International Law 248, 250.
} 
characteristics of a state which he believes are important for fostering peace: (1) a monopoly of legitimate violence; (2) the accountability of government; (3) the protection of fundamental human rights; (4) the maintenance of a basic floor of economic justice; and (5) gender equality (pp 108-109).

Support for Bellamy's focus on the state can be found in the literature on 'human security'. Barry Buzan has branded human security as a reductionist concept that adds little analytical value and reiterates that states are a "necessary condition for individual security because without the state it is not clear what other agency is to act on behalf of individuals." ${ }^{\text {, }}$ Other authors on human security have suggested the absence of a state and its institutions can in fact be damaging to human security. ${ }^{14}$ When a state does not protect its own citizens 'people themselves are the main agents to provide at least some protection for themselves and others around. ${ }^{15}$ But we must note '[p]eople are not passive recipients of "security", or victims of its absence, but active subjects who can contribute directly to identifying and implementing solutions to security problems. ${ }^{16}$ Bellamy and McDonald noted in 2002 that states can often be agents of insecurity and "the co-option of human security into a statist policy framework risks limiting the emancipatory potential of this security discourse." ${ }^{17}$ The state does not provide security and consequently contribute to world peace in isolation. To achieve Bellamy's vision of world peace we need to reshape the priorities of the state and give space for individuals to challenge and influence statist policy frameworks. The human security discourse has attempted to both change the priorities of the state, towards a people-focused approach to security, and open the provision of security to a wider sphere of actors who may be able to either inform decision making or better provide the necessary security. ${ }^{18} \mathrm{~A}$ similar approach is needed with regards to peace. States must adapt their decision-making processes to better identify and promote methods of achieving peace that mitigate the geopolitical self-interests that typically prevail.

One could argue Bellamy's above five characteristics of a state support the construction of the liberal peace, but in actuality Bellamy avoids grounding his suggestions in specific existing regimes and international systems. For example, when discussing the primacy of human rights, no mention is made of requiring states to ratify existing human rights treaties or

\footnotetext{
${ }^{13}$ Barry Buzan, 'A Reductionist, Idealistic Notion that Adds Little Analytical Value' (2004) 35 Security Dialogue 369; Barry Buzan, 'Human Security in International Perspective' in Mely Caballero-Anthony and Jawhar Hassan (eds), The Asia Pacific in the New Millennium: Political and Security Challenges (Institute of Strategic and International Studies 2001) 583.

${ }^{14}$ Shahrbanou Tadjbakhsh, 'Human Security: Concepts and Implications with an Application to PostIntervention Challenges in Afghanistan' (Les Études du CERI No 117-118, Sciences Po, 2005) 24; Fairlie Chappuis, 'Human security and security sector reform: conceptual convergences in theory and practice' in: Wolfgang Benedek, Matthias Kettemann and Markus Möstl (eds), Mainstreaming Human Security in Peace Operations and Crisis Management (Routledge 2011) 99, 109-110; See also Mient Jan Faber, 'Human Security from Below: Freedom from Fear and Lifeline Operations', in Monica den Boer and Jaap de Wilde (eds), The Viability of Human Security (Amsterdam University Press 2008).

${ }^{15}$ Faber (n 14) 156.

${ }^{16}$ Tadjbakhsh, (n 14) 25; See also Alexander Gilder, 'International and human security in the kaleidoscopic world' (2020) Indian Journal of International Law 1-25 (e-pub ahead of print). ${ }^{17}$ Alex J Bellamy and Matt McDonald, "The Utility of Human Security': Which Humans? What Security? A Reply to Thomas \& Tow’ (2002) 33 Security Dialogue 373, 374.

${ }^{18}$ Gilder (n 16) 17.
} 
enforcing the obligations through current UN treaty bodies (pp 111-112). This is important as it harks back to previous comments above with regards to taking a critical view of the prevailing norms and history of international law. Some have traditionally viewed international law and importantly state sovereignty as a tool of subjugation, which cannot simply be rectified by introducing human-focused regimes, such as human rights or economic focuses on sustainable development. For instance,

'Western states argued that they were not bound by the principles authored by the Third World because of the basic rule that a state could not be bound by international rules unless it agreed to be so bound. Nevertheless, the West proceeded to argue, the Third World was bound by the older rules of international economic law that the West had authored. Indeed, the West argued, acceptance of these and the other established rules of the international system was a condition of becoming an independent, sovereign state.'19

Importantly, TWAIL authors have noted how states in the global North "embrace[] a divisive universalism" and that "[f]or many, colonialism is an anomaly of the past, now corrected by processes of universalism and of no further relevance as a conceptual category." 20 Whereas forceful arguments have been made that Europe's policies continue to be profoundly imperial alongside critiques of regimes such as international human rights law, international economic law, and international environmental law. ${ }^{21}$ Suggestions for achieving world peace will need to engage with the notion that 'everyday imperialism' continues in the day-to-day lives of the global South. ${ }^{22}$

Moving to international organisations (IOs) Bellamy suggests they are one method used to manage the contagion of war ( $p$ p 94-95). However, Bellamy says it is states as the primary institutions that foster cleavages in our relationships across the world and divisions that cause war whereas IOs are secondary institutions. But there is a deeper issue that can be explored here. Bellamy does not assess why it remains the case that IOs are unable to prevent these cleavages? The UN has certainly been more successful in preventing inter-state conflict than the League of Nations, but conflict overall still persists highlighting how we continue to organise ourselves into groups that wage war. Judge Abdulqawi Yusuf notes,

'[w]e have not yet achieved a full shift from a 'society' to a 'community of nations'. Despite the reference in many multilateral instruments to the 'common concern' of humanity, we see major initiatives launched by international organisations to address this 'common concern' amputated,

\footnotetext{
${ }^{19}$ Antony Anghie, 'The evolution of international law: Colonial and postcolonial realities' (2006) 27 Third World Quarterly 739, 749.

${ }^{20}$ B.S. Chimni, 'The Past, Present and Future of International Law: A Critical Third World Approach' (2004) 8 Melbourne Journal of International Law 499; John Reynolds, Empire, Emergency and International Law (Cambridge University Press 2017) 16; See also, Mohsen al Attar, 'Reframing the "Universality” of International Law in a Globalizing World' (2013) 59 McGill Law Journal 95.

${ }^{21}$ Antony Anghie, 'Europe and International Law's Colonial Present' (2012) 6 Baltic Yearbook of International Law 79, 82; See, eg, Anghie (n 19) 749; Makau Mutua, 'Savages, Victims, and Saviors: The Metaphor of Human Rights' (2001) 42 Harvard International Law Journal 201; Brian-Vincent Ikejiaku, 'International Law is Western Made Global Law: The Perception of Third-World Category' (2013) 6 African Journal of Legal Studies 337.

${ }^{22}$ Anghie (n 21) 82.
} 
Author accepted manuscript - forthcoming in the Journal of International Humanitarian Legal Studies

curtailed, or outright rejected when they collide with individual State interests (sometimes interests of the moment) of powerful stakeholders. ${ }^{23}$

It may be the case that current IOs are advancing values that are not truly universal and are tainted by colonial legacies, such as how colonial powers remain permanent Security Council members. ${ }^{24}$ How then can the primary institutions (states) ever truly reconcile their differences even when brought together by a current IO?

For example, exacerbating the issues surrounding IOs, Bellamy says ' $[w]$ hen the Great Powers are united, the Security Council can be an immense force for world peace...' (p 146). Forming a link between the so-called Great Powers and world peace can be troubling for some, particularly the global South. A narrow focus on the Security Council can be exclusionary, emphasising the preoccupation of many scholars with the primacy of the Security Council and the repression of thought to the confines of existing mechanisms of international law. To present a more balanced view, what should be mentioned alongside the Security Council is the global South's efforts in the General Assembly over the last 60 years. For example, the Declaration on the Granting of Independence to Colonial Countries and Peoples and Declaration on Principles of International Law Concerning Friendly Relations and Cooperation among States represent key documents where new states in the global South were pivotal. ${ }^{25} \mathrm{~A}$ focus on the Security Council in relation to achieving world peace risks perpetuating the view that the traditional order of international organisations remaining under the control of traditional powers is the only path forward.

\section{Bellamy's articles for world peace}

Chapter 8 outlines Bellamy's core suggestions for how we can move toward world peace. Bellamy's suggestions are presented in the form of a treaty with six 'preliminary articles for world peace in our time', three 'definitive articles for world peace in our time' and one 'additional imperative article for world peace in our time' (pp 175-176). International lawyers will be particularly interested in the drafting choices made in these Articles and the resulting technicalities but there is not the space in this review essay to engage with all the articles. A few specific points will instead be focused on. What is immediately notable is that the articles are embedded in the existing systems of international law and relations. Bellamy's suggestions are therefore not iconoclastic. For instance, the Security Council takes a prominent place in the first preliminary article. The articles are also clearly premised on a few trends including fairness and accountability. One risk of formulating articles that promote some of the existing norms, such as human rights, is that they could be viewed as part of the liberal peace. Bellamy does though lament the failures of liberal peacebuilding (pp 176-177).

Preliminary Article 1 reiterates that ' $[\mathrm{n}] \mathrm{o}$ one may violate the rules of international law relating to the use of force and conduct of armed conflict' and also states permanent members

\footnotetext{
${ }^{23}$ Abdulqawi Ahmed Yusuf, 'Engaging with International Law' (2020) 69 International and Comparative Law Quarterly 505, 508.

${ }^{24}$ For an alternative view see Otto Spijkers, 'Global Values and the Institutions of the United Nations' (2017) 11 Vienna Journal of International Constitutional Law 211.

${ }^{25}$ Georges Abi-Saab, 'The Third World intellectual in praxis: confrontation, participation, or operation behind enemy lines?' (2016) 37 Third World Quarterly 1957, 1959.
} 
of the Security Council may not use their veto to prevent collective action in response to armed aggression or international crimes ( $p$ 179). Bellamy supports this article by stating the '[i]nternational order rests on mutually agreed laws' ( $\mathrm{p}$ 179, emphasis added). He also discusses how we have a shortage of compliance, not a shortage of law, and we must push states towards compliance (pp 180-181). One issue to raise here is that we need to think more deeply about compliance beyond the geopolitical reasons for non-compliance. It is true we do not have a shortage of law, but is the law reflective of global society? Does it encompass values of all humankind that could positively engender compliance or does the existing law all too often pit one state against another creating an us vs them rhetoric? Bellamy draws on IHL saying the law of armed conflict 'prevents actors justifying the commission of great harm in the name of world peace' ( $p$ 182). This can again be countered with the view that IHL does allow great harm by facilitating banal violence against military targets and civilians as collateral damage. If articles for world peace are formulated, we must question whether our collection of laws are the right ones or could we do better at preventing banal violence through law?

Bellamy also suggests making the use of the veto much more costly politically (p 186). He rightfully states it would be unlikely for the permanent members of the Security Council to voluntarily abstain from using their veto and suggests using the Uniting for Peace resolution to circumvent the Security Council. Bellamy believes that only then will the Security Council re-evaluate their decisions to avoid being made irrelevant (p 187). Graham Melling and Anne Dennett have suggested in a recent article that Uniting for Peace could be used to respond to mass atrocities where a veto has been used illegitimately. ${ }^{26}$ Legitimacy is a thread that runs through Bellamy's articles with the first definitive article suggesting '[e]ach state shall be a capable, responsible, and legitimate sovereign' ( $p$ 175, emphasis added). Legitimacy, and responsibility for that matter, is necessarily subjective but Bellamy does not discuss any further interventions from the General Assembly that could engender more legitimate responses as opposed to the Security Council.

The last point to be made here is the importance of community and the growing global society in a world where issues cannot be resolved by one state no matter how powerful that state is. ${ }^{27}$ Bellamy's fourth definitive article declares '[s]tates shall establish and sustain security communities with their neighbours' to promote states to think about community in the international space ( $\mathrm{p}$ 194). There is a risk with this suggestion that regional divides could become more, not less ingrained resulting is the divisions that cause war. But Bellamy importantly notes that regional communities can be 'an important bridge between local and national ... and global' (p 197). Building on this, the fifth definitive article states '[i]ndividuals should enjoy a universal right of hospitality. No state shall inhibit the free and fair movement of goods, services, people, and ideas between them' ( $p$ 197). Bellamy alludes to online communication by discussing how people can connect with like-minded people in transnational networks, but this is more important that Bellamy lets on. The exponential increase in global

\footnotetext{
${ }^{26}$ Graham Melling and Anne Dennett, 'The Security Council veto and Syria: responding to mass atrocities through the "Uniting for Peace" resolution' (2017) 57 Indian Journal of International Law 285.

${ }^{27}$ Yusuf (n 23) 508.
} 
online communities will shape the future of international law, the legitimacy of the actors that have international legal personality and ultimately, world peace.

Bellamy's additional imperative article suggests '[i]ndividuals should organize and do what they reasonable can to support peace' ( $p$ 211). It is mentioned how civil society can reach out globally and create 'overlapping and cosmopolitan identities and interests' that diminish what divides us ( $\mathrm{p}$ 211). This is true but it must be said that online communication transcends the state in so many ways. It may be the case that issues can garner positive global attention through online platforms that bring actors together. For instance, the global discussion of the Anthropocene and impact of climate change has grown exponentially because of the large followings of activists like Greta Thunberg and transnational groups such as Extinction Rebellion. UN initiatives like the 2018 General Assembly Resolution Towards a Global Pact for the Environment and suggestions from scholars such as Louis Kotze's proposal for an 'Earth system law' may gain more traction within these non-state transnational groups in the new global discourse. ${ }^{28}$ However, online discourses can also be used to spread pernicious misinformation on a huge scale. ${ }^{29}$ In India, WhatsApp has been used to spread misinformation, which has led to a number of deaths and violent attacks since $2015 .{ }^{30}$ It is increasingly difficult for states to regulate online activities and rapidly shared misinformation can quickly create crises of their own. ${ }^{31}$ Any articles for world peace will need to recognise this dynamic and ensure that non-traditional actors can access the international system for the system to remain legitimate while protecting against harmful discourses based on misinformation. ${ }^{32}$

\section{Conclusion}

World Peace is a work deserving of further critical engagement to dissect the steps toward world peace. International law scholarship can often seem preoccupied by conflict with authors suggesting changes that need to be made to particular regimes, but it is rare to see a piece of work that brings together a broad array of issues to suggest a path forward towards peace. The book often takes a grand historical view that misses the minutiae from an international law perspective, but that is of course not the purpose of the book and the grand historical view certainly has its benefits. It provides an accessible account of the history of peace and several of the power structures behind the guise of states and the systems in which they reside. The greatest achievement of this work is that it skilfully brings together countless important works

\footnotetext{
${ }^{28}$ UN General Assembly, 'Towards a Global Pact for the Environment' (14 May 2018) A/RES/72/277; Duncan French and Louis Kotze, "Towards a global pact for the environment': international environmental law's factual, technical and (unmentionable) normative gaps' (2019) 28 Review of European, Comparative and International Environmental Law 25; Louis Kotze, 'Earth system law for the Anthropocene: rethinking environmental law alongside the Earth system metaphor' (2020) 11 Transnational Legal Theory 75.

${ }^{29}$ Edith Brown Weiss, 'The Emerging International System and Sustainable Development' (2000) 1 International Review for Environmental Strategies 9, 11; Edith Brown Weiss, 'International Law in a Kaleidoscopic World' (2011) 1 Asian Journal of International Law 21, 29-30.

${ }^{30}$ Shakuntala Banaji and Ram Bhat, 'WhatsApp Vigilantes: An exploration of citizen reception and circulation of WhatsApp misinformation linked to mob violence in India' (LSE Department of Media and Communications 2019) <http://www.lse.ac.uk/media-andcommunications/assets/documents/research/projects/WhatsApp-Misinformation-Report.pdf>.

${ }^{31}$ Gilder (n 16) 6.

${ }^{32}$ Ibid. 14.
} 
Author accepted manuscript - forthcoming in the Journal of International Humanitarian Legal Studies (2020) 11(2)

from over the centuries to form a concise account of world peace, which can be built on across a broad range of disciplines. World Peace provides an excellent foundation for international lawyers to think more deeply about peace, to undertake critical histories and, like I have started to do in this review, flesh out the details that international law will need to resolve to improve our chances of achieving world peace. Scholarship on international law will, in the future, need to think more resolutely about how the law's existing systems and regimes help or hinder peace. 